\title{
Growth analysis of sweet pepper cultivated in coconut fiber in a greenhouse
}

\author{
Hamilton César de O Charlo; ; Sueyde F de Oliveira²; Renata Castoldi'; Pablo F Vargas³ Leila T Braz²; \\ José Carlos Barbosa ${ }^{4}$ \\ ${ }^{1}$ Instituto Federal de Educação, Ciência e Tecnologia do Triângulo Mineiro (IFTM), R. João Batista Ribeiro 4000, Mercês, 38064- \\ 790 Uberaba-MG; ${ }^{2}$ UNESP-FCAV, Depto. Prod. Vegetal, Rod. Prof. Paulo Donato Castellane, s/n, 14884-900 Jaboticabal-SP; \\ hamiltoncharlo@gmail.com; ${ }^{3}$ UEMG, Av. Juca Stockler, 1130, 37900-106 Passos-MG; ${ }^{4}$ UNESP-FCAV, Depto. Ciências Exatas
}

\begin{abstract}
Knowledge about the growth of crops allows the planning of rational cultivation methods which contribute to achieve greater potential of plant species, besides supplying information for the construction of descriptive mathematical models of growth. The growth curve of sweet pepper (Eppo hybrid), cultivated in coconut fiber in a greenhouse with fertirrigation, was determined. The experiment consisted initially of 160 plants divided into four blocks. Two plants were analyzed per block every 21 days after transplanting, ending at 189 days after transplant. The cultivation was carried out in plastics pots of $13 \mathrm{~L}$ containing coconut fiber, which were arranged in double rows, spaced $0.5 \times 0.8 \mathrm{~m}$ between simple rows and $1.1 \mathrm{~m}$ between double rows. In each harvest the plant growth, production and quality of mature fruits were evaluated. The dry mass of the shoot increased with time, following the experimental model exponential of first order, reaching a maximum of $451.5 \mathrm{~g} /$ plant, 189 days after transplanting (DAT). The production of dry mass of leaves, stem, root and fruit also increased over time reaching maximum values of $68.7,65.8,11.5$ and $302.9 \mathrm{~g} / \mathrm{plant}$, respectively, at 189 DAT. The same occurred with the leaf area per plant, plant height and the absolute rate of growth, whose maximum values were $6.183,5 \mathrm{~cm}^{2}$, $136.9 \mathrm{~cm}$ and $4.4 \mathrm{~g} / \mathrm{plant} /$ day, respectively. The growth of the plant was continuous throughout the cycle, and the highest amount of dry mass was accumulated in fruits, reaching a marketable production of $97.3 \mathrm{t} \mathrm{ha}^{-1}$. All fruits were classified as Extra.
\end{abstract}

Keywords: Capsicum annuum, growth analysis, fertirrigation.

\section{RESUMO}

Análise de crescimento de pimentão cultivado em fibra de coco em ambiente protegido

O conhecimento sobre o crescimento das culturas permite o planejamento de métodos de cultivo racional, que contribuirá para alcançar um maior potencial de espécies vegetais, além de fornecer informações para a construção de modelos matemáticos descritivos de crescimento. Diante disto, o objetivo deste estudo foi determinar a curva de crescimento do pimentão amarelo (híbrido Eppo) cultivado em fibra de coco em ambiente protegido com fertirrigação. $\mathrm{O}$ experimento compreendeu inicialmente 160 plantas, divididas em quatro blocos, sendo colhidas duas por bloco a cada 21 dias após o transplante, finalizando-se aos 189 dias após o transplante. O cultivo de pimentão foi feito em vasos plásticos de 13 L contendo fibra de coco, distribuídos em fila dupla, com espaçamento de 0,5 x $0,8 \mathrm{~m}$ entre fileiras simples e 1,1 m entre fileiras duplas. Em cada colheita foram avaliados o crescimento das plantas e a produção e qualidade de frutos maduros. A massa seca da parte aérea aumentou com o tempo, seguindo um modelo exponencial de primeira ordem, atingindo um máximo de 451,5 g/planta aos 189 dias após o transplante (DAT). A produção de massa seca de folhas, caule, raiz e frutos também aumentou ao longo do tempo, seguindo o mesmo modelo, atingindo valores máximos de 68.7, 65.8, 11.5 e $302.9 \mathrm{~g} /$ planta, respectivamente, aos 189 DAT. O mesmo ocorreu com a área foliar por planta, altura da planta e a taxa de crescimento absoluto, cujos valores máximos foram de $6.183,5 \mathrm{~cm}^{2}, 136.9 \mathrm{~cm}$ e $4.4 \mathrm{~g} / \mathrm{planta} / \mathrm{dia}$, respectivamente. $\mathrm{O}$ crescimento das plantas foi contínuo ao longo do ciclo, sendo que a maior quantidade de massa seca foi acumulada nos frutos, cuja produção comercial chegou a $97.3 \mathrm{t} \mathrm{ha}^{-1}$, sendo totalmente classificados como Extra.

Palavras-chave: Capsicum annuum, análise de crescimento, fertirrigação.

\section{(Recebido para publicação em 14 de março de 2010; aceito em15 de agosto de 2011) \\ (Received on March 14, 2010; accepted on August 15, 2011)}

$S^{*}$ weet pepper is one of the highest widespread and popular species of vegetables in Brazil, and it is considered one of the ten species of greatest economic importance in the Brazilian vegetable market. With the increasing demand of this product in that country, sweet pepper is being cultivated mainly in greenhouses. However, the practice of two or more successive cultivations has caused an increased incidence of pests and phytopathogens which survive in the soil and crop residues, such as nematodes, due to their continuous multiplication (Charlo et al. 2009).

Sweet pepper areas in São Paulo State have presented many problems with root-knot nematodes (Meloidogyne spp.), especially Meloidogyne incognita and $M$. mayaguensis which reduce the yield of the culture. There exists a lack of sweet pepper cultivars resistant to these nematodes, which mean frequent change in cultivation areas or the need of pesticides for soil treatment, resulting in negative environmental impacts. One possible solution for this problem is the cultivation in pots or bags filled with substrate.

Sweet pepper cultivation in pots is a recent technique, and therefore there are few published studies presenting useful data with appropriate technical 
recommendations. Charlo et al. (2009), evaluating five sweet pepper hybrids in greenhouse utilizing coconut fiber, found that the hybrid Eppo is one of the most productive with 102.9 tha $^{-1}$ beyond having excellent fruit characteristics.

Knowledge about plant growth depending on time allows the planning of rational cultivation methods which contribute to achieve greater potential of plant species, besides supplying informations for the construction of descriptive mathematical models. The aim of the principles and practices of growth analysis is to describe and interpret the performance of species grown in the field or in a controlled environment (Hunt, 1990).

The economic production of a cultivar is the sum of all plantenvironment interactions, but to understand a little of the nature of the internal controls inherent of cultivar, it is necessary to measure more details than just production. Such knowledge is also essential to develop models to test the growth and production of a crop. These informations are obtained at certain intervals of time during the crop growing season. The variations of biomass and leaf area amount are used, over time, to estimate the various physiological indices such as absolute rate of growth, relative rate of growth, net assimilation rate, crop growth rate, index leaf area, among others.

Identify the behavior of sweet pepper growth, through the measurement of dry matter accumulation by plant, or dried plant parts (leaves, stems, fruits and roots) is fundamental to the planning of cultivation methods that express the maximum productive potential of plants.

Therefore, the aim of the present work was to evaluate the growth curve of sweet pepper (Eppo hybrid) cultivated in pots containing fertirrigated coconut fiber in greenhouse cultivation.

\section{MATERIAL AND METHODS}

The study was carried out in a greenhouse, arch type roof with wall height of $3 \mathrm{~m}$, built of metal. The structure was covered with a transparent polyethylene film, activated against ultraviolet rays, with thickness of 150 micrometers. The sides were protected with black polypropylene screen with $50 \%$ shading. The greenhouse was located in the Sector of Vegetable Crops and Medicinal Aromatic Plants of UNESP in Jaboticabal, São Paulo State, Brazil.

The experiment consisted initially of 160 plants which were evaluated every 21 days after transplanting by removing two plants of each block until 189 days after transplanting. The sweet pepper hybrid evaluated was Eppo (Syngenta Seeds). This hybrid cultivar is a compact plant with short internodes and produces yellow fruits which are smooth and have a thick pulp. It shows resistance to cucumber mosaic virus (CMV) and tolerance to tomato spotted wilt virus (TSWV) (Syngenta, 2009).

For seedlings formation, (May $\left.1^{\text {th }}, 2006\right)$, Plantmax Hortaliças ${ }^{\circledR}$ HT substrate was used in styrofoam trays with 128 cells. In each cell was sown one seed. After seeding, the trays were acclimated in a greenhouse, receiving irrigation three to four times a day.

At 33 days after seeding (DAS), the seedlings were transplanted to plastic cups of $300 \mathrm{~mL}$, where they remained for 10 days to guarantee roots growth, and when they had five to eight definitive leaves and approximately 12 $\mathrm{cm}$ height, they were transplanted to pots in their definitive location.

Sweet pepper seedlings were grown further in plastic pots of $13 \mathrm{~L}$, filled with coconut fiber (Golden Mix ${ }^{\circledR}$ Misto 98). One seedling was transplanted in each pot, and the pots were placed in double rows, spaced $0.5 \times 0.8 \mathrm{~m}$ between simple rows and $1.1 \mathrm{~m}$ between double rows. The coconut fiber has the following physical and chemical characteristics: total porosity of $94 \%$, aeration capacity of $35 \%$, available water retention capacity of $41 \%$ (Amafibra, s.d. ${ }^{1}$ ) and the following chemical characteristics: $\mathrm{pH}=5.1$, electrical conductivity of 1.0 $\mathrm{dS} / \mathrm{m}, 8.1 \mathrm{mg} / \mathrm{L}$ of nitrate- $\mathrm{N}, 53.0 \mathrm{mg} / \mathrm{L}$ of phosphorus, $44.6 \mathrm{mg} / \mathrm{L}$ of chloride, $92.1 \mathrm{mg} / \mathrm{L}$ of sulfur; $17.7 \mathrm{mg} / \mathrm{L}$ of ammonia-N, $270.1 \mathrm{mg} / \mathrm{L}$ of potassium, $12.6 \mathrm{mg} / \mathrm{L}$ of sodium, $9.9 \mathrm{mg} / \mathrm{L}$ of calcium; $6.6 \mathrm{mg} / \mathrm{L}$ of magnesium; 0.5 $\mathrm{mg} / \mathrm{L}$ of boron, $0.1 \mathrm{mg} / \mathrm{L}$ of copper, 0.4 $\mathrm{mg} / \mathrm{L}$ of iron, $0.1 \mathrm{mg} / \mathrm{L}$ of manganese and $0.5 \mathrm{mg} / \mathrm{L}$ of zinc.

Sweet pepper cultivation was fertirrigated with the nutritive solution recommended by Trani \& Carrijo (2004). The following chemicals were used to prepare $1000 \mathrm{~L}$ of the solution: calcium nitrate $(650 \mathrm{~g})$, potassium nitrate (500 g), monopotassium phosphate $(170 \mathrm{~g})$, magnesium sulfate $(250 \mathrm{~g})$, magnesium nitrate $(50 \mathrm{~g})$, iron-EDTA (11 $\mathrm{g}$ of iron chloride $+15 \mathrm{~g}$ of disodium EDTA) and $150 \mathrm{~mL}$ of a stock solution of micronutrients. This stock solution of micronutrients was prepared with $16.7 \mathrm{~g}$ of boric acid, $15 \mathrm{~g}$ of manganese chloride, $0.8 \mathrm{~g}$ of copper chloride, $0.3 \mathrm{~g}$ of molybdenum oxide and $2.6 \mathrm{~g}$ of zinc sulfate, dissolved in $1 \mathrm{~L}$ of water.

To promote the flow of the drainage water and thereby reduce the humidity in the greenhouse, the ground was covered with pieces of rock and the pots were placed on wooden supports near the floor.

The plants were pruned to have four main stems and staked individually in the shape of a "V." For the control of both pests and diseases, the management adopted was performed upon visual detection of the agent, insect or pathogen, in accordance to the technical recommendations of the chemical product utilized.

The insecticides utilized were: abamectin, thiacloprid, thiamethoxam, formetanate and pirimicarb, for the control of the following pests: vegetable leaf miner (Liriomyza spp.), two-spotted spider mite (Tetranychus urticae), thrips (Frankliniella schultzei), cucurbit beetle (Diabrotica speciosa), green peach aphid (Myzus persicae) and silverleaf white fly (Bemisia argentifolli). The fungicides utilized were azoxystrobin, mancozeb and chlorothalonil + methyl thiophanate, for the control of the following diseases: blight (Phytophthora

${ }^{1}$ AMAFIBRA, Fibras e substratos agrícolas da Amazonia Ltda. s.d. Holambra-SP. 
capsici), anthracnose (Colletotrichum gloeosporioides), cercosporiosis (Cercospora melangena) and mildew (Oidio spp.).

To evaluate the growth curve of the sweet pepper, the height of the plant and number of fruits, flowers and leaves were determined. The plants sampled were removed from the pots, divided into roots, stem, leaves and fruits. The leaf area was also measured and the organs were dried and weighed.

Based on the collected data we calculated the absolute and relative rates of growth of plant; proportion of leaf area; proportion of leaf mass; proportion of mass of fruits and specific leaf area. These calculations were based on the method described by Evans (1972) and Benincasa (1988).

The obtained growth characteristics were submitted to regression analysis, where the age of the plant was considered the independent variable expressed in days after transplanting. For the plants growth analysis, a logistic model was used, which is widely employed to represent empirical data of growth of animals and plants (Hoffman \& Vieira, 1977). A polynomial function was used when more appropriate for each characteristic.

Fruit harvesting was performed weekly, when at least $70 \%$ of its surface was yellow, which was done between 98 days to 189 DAS. For the yield determination, six plants were evaluated from a block. After harvest, the fruits were rapidly taken to the laboratory where the following parameters were determined: average fruits length (LAF), average fruits diameter (DAF), length/ diameter ratio (L/D), average pulp thickness (PTA); average number of seeds (NAS); average weight of seeds (WAS); average weight of placenta (WAP); level of soluble solids (LSS) (determined with a portable refractometer), $\mathrm{pH}$, titratable acidity (TA). TA was determined by adding $40 \mathrm{~mL}$ of distilled water to a $10 \mathrm{~mL}$ aliquot of fruit juice along with three drops of $1 \%$ alcoholic phenolphthalein indicator. With the solution being titrated with a $0.1 \mathrm{~N} \mathrm{NaOH}$. The data were expressed as percentage of citric acid. The number of fruits per plant
(NFP) and weekly distribution, total production per plant (TPP) and weekly distribution, average mass of fruits (MAF), total and marketable yield (ETYH and ECYH) and classification of the fruits were recorded during the harvests.

The classification of the fruits was based on the measurements of their length and diameter, which determined the class and subclass, respectively. Shape and coloration of the fruits were also identified, which determined the group and subgroup, respectively. The determination of marketable quality was based on the characterization and quantification of defects considered serious and slight. Therefore, the categories of the sweet pepper fruits were based on the limits of tolerance for these defects, allowing classification as Extra, Category I, Category II and Category III, according to the regulations of Companhia de Entrepostos e Armazens Gerais de São Paulo (CEAGESP) to improve the marketable standards of vegetables in Sao Paulo State (São Paulo, 1998).

\section{RESULTS AND DISCUSSION}

There was continuous accumulation of plant dry mass (PDM) over the entire cultivation cycle (Figure 1A), where a maximum of 451.5 g plant $^{-1}$ was attained at 189 DAT. Plants needed 126 days to accumulate $50 \%$ of its dry mass. Fontes et al. (2005) found in sweet peppers grown (Elisa hybrid) in soil that the maximum accumulation of dry matter of the aerial part was $368.1 \mathrm{~g} /$ plant at 224 days of cultivation after transplanting.

Figure 1B displays a continuous accumulation of total dry mass of leaves (TDML), with a maximum of $68.7 \mathrm{~g} /$ plant being attained at 189 DAS. The maximum accumulation of dry mass of green leaves (DMGL) was estabilished at 168 days after transplanting, with the start of senescence of the plant and the appearance of senescent leaves, where 98 days were necessary for the plant to accumulate $50 \%$ of the total dry mass of green leaves.

The dry mass accumulation for stem was constant, where the maximum was obtained at 189 days after transplanting, with a value of $65.8 \mathrm{~g} / \mathrm{plant}$ (Figure 1C).

The maximum accumulation of dry mass of the roots was observed to reach at 189 days after transplanting with 11.5 $\mathrm{g} /$ plant, showing the plants $50 \%$ of total accumulation of dry mass of roots at 77 days (Figure 1D).

The accumulation of total dry mass of fruits (TDMFt) was continuous over the cultivation cycle, reaching a maximum value of $302.9 \mathrm{~g} / \mathrm{plant}$ at 189 days after transplanting (Figure 2A). The maximum value of dry mass of green fruits accumulation (DMGFt) was observed at 147 DAS with $105 \mathrm{~g} /$ plant; after this occurred a decline of the ripening of fruits (Figure 2A), which accounted for the continuous increase in the accumulation of dry mass of mature fruits (DMMFt), reaching its maximum at 189 days after transplanting, with a value of $271.6 \mathrm{~g} /$ plant(Figure 2A).

Analyzing the partition of the dry matter of the plants, it was seen that from the start of fruiting at 42 DAT until the end of the cycle, the fruits were main sinks of the plant, that is, those that showed the greatest accumulation of dry mass, as observed also by Hall (1977), Bhatt \& Srinivasa (1997) and Fontes et al. (2005).

Plant height reached a maximum of $136.9 \mathrm{~cm}$ at 189 days after transplanting (Figure 2B), where 112 days were necessary for the plants to reach $50 \%$ of the maximum height. Fontes et al. (2005) obtained for sweet pepper (Elisa hybrid) grown in soil, plants with a height of $91 \mathrm{~cm}$ at 224 days after transplanting.

The number of green leaves increased continuously up to 189 days after transplanting, when the number reached a maximum of 86.8 leaves/ plant (Figure 2C). However, the number of green leaves per plant did plateau at 168 days after transplanting, with senescence of the leaves.

The leaf area of the plants reached a maximum of $6,183.5 \mathrm{~cm}^{2} /$ plant at 189 days after transplanting, where at 72 days after transplanting the plant showed $50 \%$ of the maximum leaf area. From 147 to 189 days after transplanting, there was a tendency toward stabilization of 


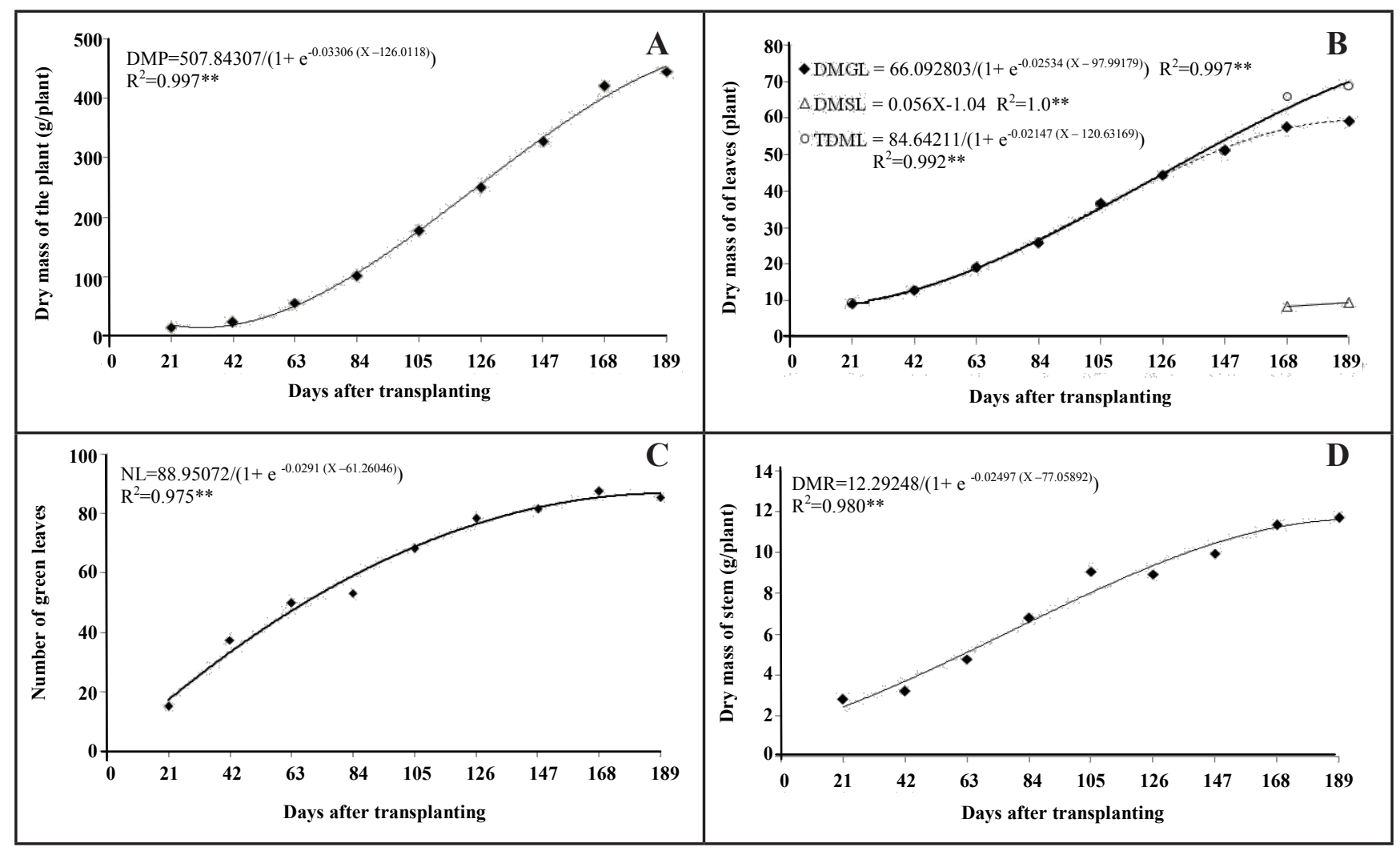

Figure 1. Dry mass of plant (DMP) (1A), of leaves (TDML), of green leaves (DMGL), of senescent leaves (DMSL) (1B), of stem (DMS) (1C) and of roots (DMR) (1D) of sweet pepper, hybrid Eppo depending on plant age (massa seca da planta (DMP) (1A), de folhas (TDML), de folhas verdes (DMGL), de folhas senescentes (DMSL) (1B), do caule (DMS) (1C) e das raízes (DMR) (1D) do híbrido de pimentão Eppo, em função da idade da planta). Jaboticabal, UNESP, 2009.

the leaf area of the plant, with the start of the senescence of the leaves (Figure 2D). Fontes et al. (2005) found for sweet pepper (Elisa hybrid) a maximum leaf area of $9,056 \mathrm{~cm}^{2} /$ plant at 224 days after transplanting. Bakker \& Van Uffelen (1988), under climatized greenhouse conditions with temperature varying at $18-24^{\circ} \mathrm{C}$, found $6,293 \mathrm{~cm}^{2} /$ plant at 75 DAS for cultivar 'Delphin'. At this time, the leaf area in the present study was approximately $3,315 \mathrm{~cm}^{2}$. These differences in leaf area can be associated with different environmental conditions and different genotypes used in each experiment.

The absolute rate of growth (ARG) reached a maximum of $4.47 \mathrm{~g} / \mathrm{plant} /$ day, or $11.1 \mathrm{~g} / \mathrm{m}^{2} /$ day, at 168 days after transplanting (Table 1). Fontes et al. (2005) found for this period an absolute rate of growth of $2.2 \mathrm{~g} / \mathrm{plant} /$ day. Beese et al. (1982) determined an ARG of 16.4 $\mathrm{g} / \mathrm{m} /$ day for sweet pepper crops between 100 and 140 days after emergence of the plants. Different values for growth rate of the crop can be due to various factors, among them being cultivar, density of planting, and management of environmental conditions (Fontes et al., 2005). The plants underwent the vegetative phase in autumn and winter, a period in which the temperature was falling, which could have affected negatively the development of the crop.

The relative rate of growth (RRG) was greater at 63 days after transplanting, with $40.8 \mathrm{mg} / \mathrm{g} /$ day (Table 1 ), decreasing progressively up to the end of the growing cycle (189 DAT), in accordance with the results found by various authors (Hall, 1977; Nilwik, 1981; Beese et al., 1982; Fontes et al., 2005).

The proportion of leaf area (PLA) decreased from $0.74 \mathrm{dm}^{2} / \mathrm{g}$ to $0.13 \mathrm{dm}^{2} / \mathrm{g}$ from 42 to 189 days after transplanting (Table 1). A similar behavior for the proportion of leaf area was reported by Fontes et al. (2005) who observed a decrease from 24.7 to $0.22 \mathrm{dm}^{2} / \mathrm{g}$ from 28 to 182 DAS. A decline in leaf area ratio starting 39 days after transplanting has also been found by Negreiros
(1995). Diminution of the proportion of leaf area indicates a decrease in the amount of assimilated products destined for the leaves, which could cause a reduction in the relative rate of growth (Nilwik, 1981).

The proportion of dry mass of roots was seen to decrease over time. At 21 DAT, the roots corresponded to $18.9 \%$ of dry mass of the plant, falling to $2.6 \%$ at 189 DAT. This could have occurred because the shape and size of containers marked influence on the growth of roots and shoots of the plant. In very high containers, the availability of oxigen in inferior part is reduced if the substrate is not well ventilated, which damage the breathing and root growth, and could promote the development of diseases (Souza, 1995).

The proportion of leaf mass (PLM) decreased continuously from 21 to 189 days after transplanting from 0.62 to 0.15 , respectively (Table 1 ). At the beginning of the growing cycle, the leaves represented $66.2 \%$ of the dry matter accumulated in the 


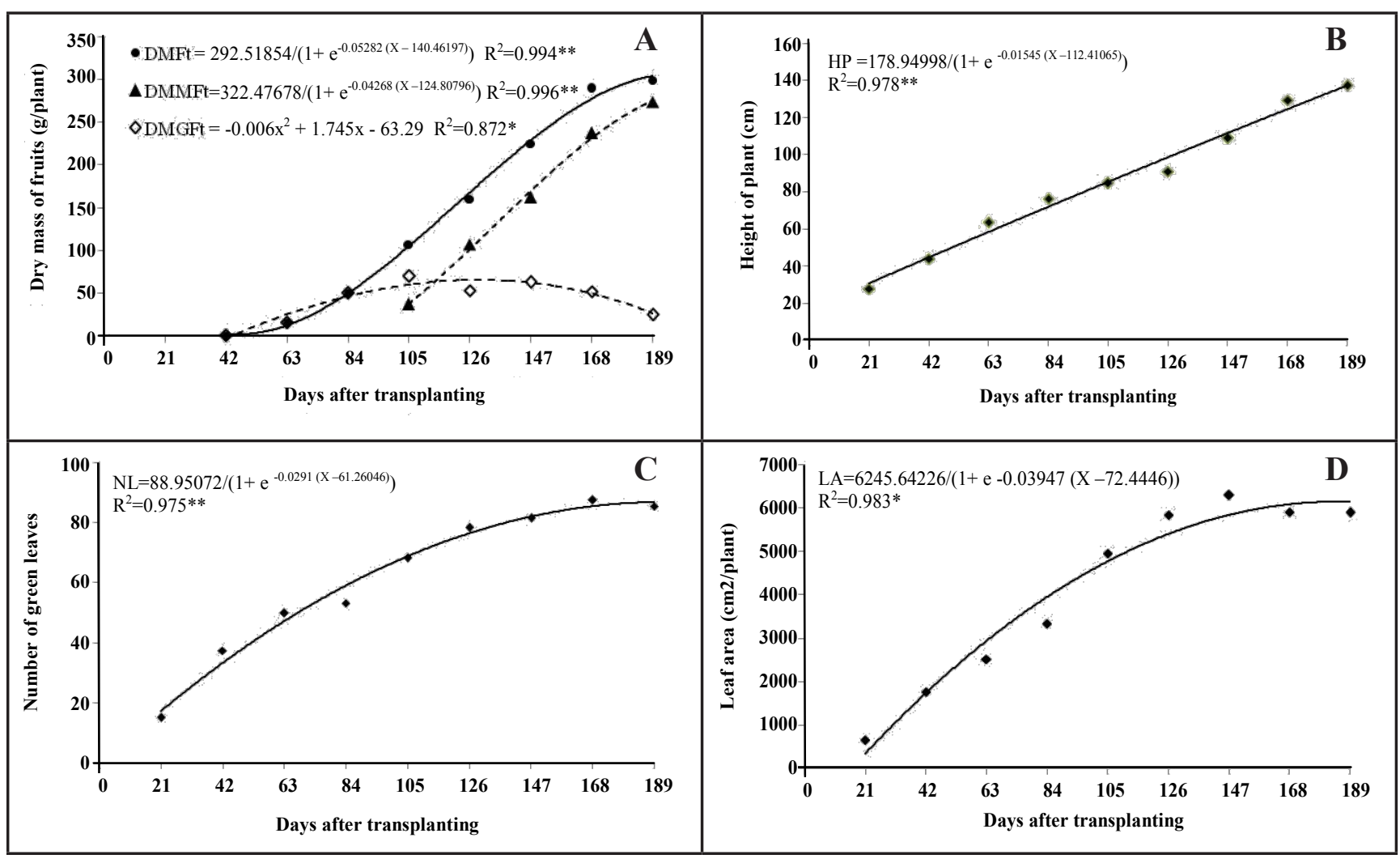

Figure 2. Dry mass of green fruits (DMGFt), dry mass of mature fruits (DMMFt), total dry mass of fruits (DMFt) (2A), height of plant (HP) (2B), number of green leaves (NL) (2C) and leaf area (LA) (2D) of Eppo sweet pepper plants, with age of plant (massa seca de frutos verdes (DMGFt), massa seca de frutos maduros (DMMFt), massa seca total de frutos (DMFt) (2A), altura da planta (HP) (2B), número de folhas verdes (NL) (2C) e area foliar (LA) (2D) de plantas de pimentão Eppo, em função da idade da planta). Jaboticabal, UNESP, 2009.

plant. However, at 189 days after transplanting, the leaves corresponded to $15.4 \%$ of the dry matter accumulated in the plant. These results agree with those obtained by Clapham \& Marsh (1987) who found decreasing values of the ratio of leaf mass in sweet pepper (Keystone Resistant Giant and Ladybell) cultivation over time.

The proportion of the stem mass was $18.9 \%$ of the dry mass of the plant at 21 DAT, and increased up to 42 DAT, the period in which the plant began to fruit. After this time, there was decrease in the percentage of dry mass of the stem in relation to the whole plant with the accumulation of dry mass of fruits.

The proportion of mass of fruits increased continually, from 42 to 147 DAT, from 0.01 to 0.68 , that is, at 42 DAT the fruits represented $0.7 \%$ of the dry matter of the plant, and at 147 DAT, $68.7 \%$. From 147 DAT to 189 DAT, there was a small decrease in the proportion of mass of fruits from 0.68 to 0.67 , respectively. Increasing values of mass of fruits were also observed by Fontes et al. (2005) who found increases of 18 to $51 \%$ of fruit dry mass in relation to the dry mass of the plant also in accordance to the results obtained by Champham \& Marsh (1987).

The specific leaf area (SLA) was greater at 42 days after transplanting (DAT), with a value of $136.26 \mathrm{~cm}^{2} / \mathrm{g}$ (Table 2). Fontes et al. (2005) found for cultivated sweet peppers (Elisa hybrid) a greater specific leaf area of $200.8 \mathrm{~cm}^{2} / \mathrm{g}$, at 42 DAT, followed by a continuous decrease down to $82.75 \mathrm{~cm}^{2} / \mathrm{g}$ at 189 DAT. Miller et al. (1979) reported that the specific leaf area of sweet pepper (Keystone Resistant Giant) decreased up to 56 DAT $\left(150 \mathrm{~cm}^{2} / \mathrm{g}\right)$ and in the subsequent period remained practically constant up to 112 DAT $\left(139 \mathrm{~cm}^{2} / \mathrm{g}\right)$. The decrease in specific leaf area with age of the plant is the result of the reduction or paralysis of the expansion of leaf area (Negreiros, 1995) along with increased rates of leaf senescence and abscission (Scott \& Batchelor, 1979).
The number of floral buds was greatest at 42 DAS, with a value of 25.3 buds plant ${ }^{-1}$, decreasing to 4 buds plant $^{-1}$ at 189 DAT (Table 2). However, the number of fruits was greatest at 105 DAT, when the plants showed 12.2 fruits/plant. It should be pointed out that the number of flowers per plant and number of fruits per plant are influenced greatly by the handling of the plants, by means of pruning and harvesting, respectively, thereby leading to large variations from one period to the next.

The level of soluble solids of the fruits was 8.1 (Table 3). Rocha et al. (2004), evaluating the chemical characteristics of sweet pepper hybrids fruits (Athenas and Magali R), observed soluble solid values ( ${ }^{\circ}$ Brix) varying from 4.4 to 4.9 . These results are different from those found in the present work. This can be related to the stage of maturation of the fruits analysis by these authors, which was not mentioned. Another possible cause of this difference can be due to the cultivars utilized, as 
Table 1. Vegetative characteristics of sweet pepper plants, Eppo hybrid. Average values of 21-day periods during the cultivation cycle (características vegetativas de plantas de híbridos de pimentão Eppo. Valores médios do período de 21 dias durante o ciclo de cultivo). Jaboticabal, UNESP, 2009.

\begin{tabular}{cccccc}
\hline $\begin{array}{c}\mathbf{A g e}^{\mathbf{1}} \\
\text { (days) }^{1}\end{array}$ & $\begin{array}{c}\text { ARG } \\
\left.\text { (g plant }^{-1} \text { day }^{-1}\right)\end{array}$ & $\begin{array}{c}\text { RRG } \\
\left(\mathbf{m g ~ g}^{-1} \mathbf{~ d a y ~}^{-1}\right)\end{array}$ & $\begin{array}{c}\text { PLA } \\
\left(\mathbf{d m}^{\mathbf{2}} \mathbf{g}^{-1}\right)\end{array}$ & PRM & PLM \\
\hline 21 & - & - & 0.44 & 0.18 & 0.62 \\
42 & 0.43 & 22.55 & 0.74 & 0.13 & 0.54 \\
63 & 1.53 & 40.75 & 0.44 & 0.08 & 0.34 \\
84 & 2.18 & 28.44 & 0.33 & 0.06 & 0.25 \\
105 & 3.61 & 26.47 & 0.27 & 0.05 & 0.20 \\
126 & 3.48 & 16.35 & 0.23 & 0.03 & 0.17 \\
147 & 3.68 & 12.80 & 0.19 & 0.03 & 0.15 \\
168 & 4.47 & 12.01 & 0.14 & 0.02 & 0.15 \\
189 & 1.15 & 2.67 & 0.13 & 0.02 & 0.15 \\
\hline
\end{tabular}

${ }^{1}$ Days after transplanting (dias após o transplante); $\mathrm{ARG}=$ absolute rate of growth (taxa de crescimento absoluto); $\mathrm{RRG}=$ relative rate of growth (taxa de crescimento relativo); PLA= proportion of leaf area (razão de área foliar); $P R M=$ proportion of root mass (razão de massa do caule); PLM= proportion of leaf mass (razão de massa de folhas).

Table 2. Proportions of stem and fruit mass, specific leaf area and number of floral buds and of fruits per plant, in sweet pepper Eppo hybrid depending on plant age (razão de massa do caule e de frutos, área foliar específica e número de botões florais e de frutos por planta em plantas de híbridos de pimentão Eppo, em função da idade da planta). Jaboticabal, UNESP, 2009.

\begin{tabular}{|c|c|c|c|c|c|}
\hline \multirow{2}{*}{$\begin{array}{c}\text { Age }^{1} \\
\text { (days) }\end{array}$} & \multirow{2}{*}{ PSM } & \multirow{2}{*}{ PFtM } & \multirow{2}{*}{$\begin{array}{c}\text { SLA } \\
\left(\mathrm{cm}^{2} / \mathrm{g}\right)\end{array}$} & Floral buds & Fruits \\
\hline & & & & \multicolumn{2}{|c|}{$\left(\mathrm{n}^{0} /\right.$ plant $)$} \\
\hline 21 & 0.18 & 0.00 & 71.05 & 7.8 & 0.0 \\
\hline 42 & 0.31 & 0.01 & 136.26 & 25.3 & 1.6 \\
\hline 63 & 0.29 & 0.27 & 131.46 & 13.5 & 6.2 \\
\hline 84 & 0.18 & 0.49 & 132.94 & 11.5 & 9.0 \\
\hline 105 & 0.14 & 0.60 & 135.19 & 10.2 & 12.2 \\
\hline 126 & 0.14 & 0.64 & 131.52 & 9.3 & 9.0 \\
\hline 147 & 0.12 & 0.68 & 123.29 & 8.1 & 9.0 \\
\hline 168 & 0.13 & 0.68 & 102.69 & 5.0 & 12.1 \\
\hline 189 & 0.14 & 0.67 & 99.66 & 4.0 & 7.3 \\
\hline
\end{tabular}

'Days after transplanting (dias após o transplante); PSM= proportions of stem mass (razão de massa do caule); PFtM= proportions of fruit mass (razão de massa de frutos); SLA= specific leaf area (area foliar específica).

they were not the same, or even that the sweet pepper production system inside a greenhouse using coconut fiber and fertirrigation, provided the plants with optimal conditions for better expressing their photosynthetic potential and accumulating greater amounts of soluble solids, since the amount of photoassimilated compounds is the result of the interaction between genotype and environment.

A mean $\mathrm{pH}$ of 4.9 was observed (Table 3), which is close to that observed by Factor (2003), who found in mature sweet pepper hybrid cultivars Matador and Zarco, in a greenhouse using a hydroponic system type nutrient film technique (NFT), verified that fruits had lengths of 8.5 and $10.7 \mathrm{~cm}$, respectively. Frizzone et al. (2001) observed that the fruits of the sub-group yellow of the cultivar Marengo Hy grown in a greenhouse had a greater mean length of $10.5 \mathrm{~cm}$.

Charlo et al. (2009) evaluated sweet pepper hybrids in coconut fiber with fertirrigation and found that the hybrids CLXP 1463, Eppo and Linea showed the greatest means of fruit diameters, with values of $7.8,7.5$ and $7.5 \mathrm{~cm}$, respectively.

The average pulp thickness was 6.9 mm (Table 3). Frizzone et al. (2001), in their studies with sweet pepper, cultivar 'Marengo HY', of the subgroup yellow, found a mean pulp thickness varying from 2.5 to $5.6 \mathrm{~mm}$. These values are lower than those obtained in the present work. It should be noted that the fruits that show a thicker pulp are more tolerant to transport, last longer post-harvest and have greater yield in mass, besides being more preferred in the market.

With regard to the length/diameter ratio, a value of 1.1 was found, that is, the fruits of this hybrid had an approximately square shape. This ratio is connected to shape of the fruit where the square-shaped fruits, also called blocks, show a length/diameter ratio closer to 1 . More elongated fruits, whether of the rectangular or conical group, have a ratio bigger than 1 (Charlo et al., 2009).

The average number of seeds per fruit was 117.1, which corresponds to $2.0 \mathrm{~g} / \mathrm{plant}$. The average weight of placenta was $18.2 \mathrm{~g} /$ plant and mean weight of placenta + seeds was $20.3 \mathrm{~g} /$ plant (Table 3).

The total production per plant was $3.9 \mathrm{~kg} / \mathrm{plant}$, with the mean number of fruits per plant being 19.5 and weight average of fruits $200 \mathrm{~g}$ (Table 3). Silva et al. (2005), evaluating the yield of yellow sweet pepper cultivars in hydroponics, observed for the cultivars Zarco and Matador 17.7 and 31.2 fruits/plant, respectively and a production/plant of $2.6 \mathrm{~kg} / \mathrm{plant}$ for the hybrid Zarco. Charlo 
Table 3. Fruit characteristics and yield of sweet pepper, Eppo hybrid, cultivated in coconut fiber with fertirrigation (características dos frutos e produtividade avaliados no pimentão 'Eppo', cultivado em fibra da casca de coco e fertirrigação). Jaboticabal, UNESP, 2009.

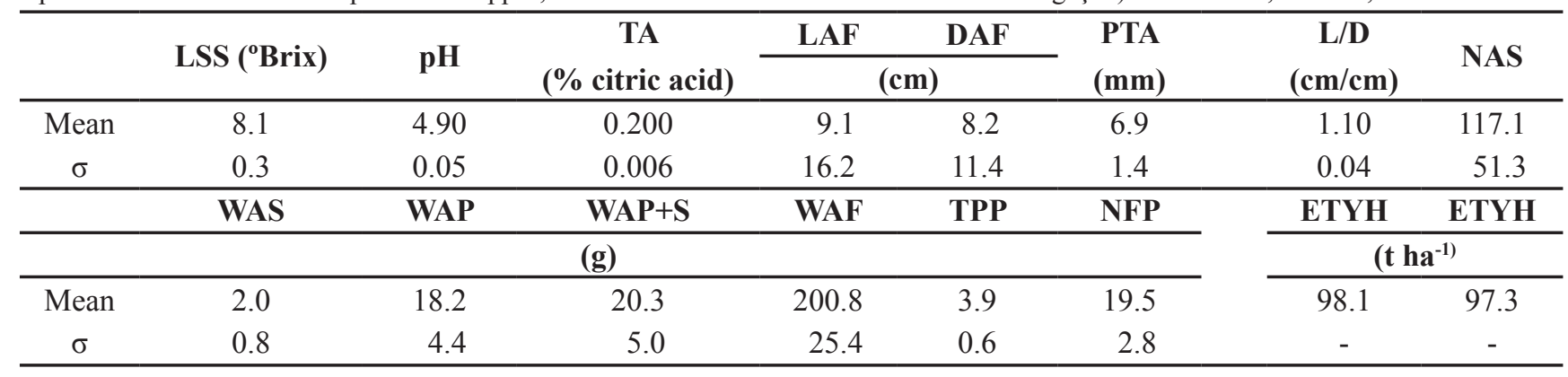

$\sigma=$ Means and standard deviation (média e desvio padrão da media); LSS= level of soluble solids (teor de sólidos solúveis); TA= titratable acidity (acidez titulável); LAF= average lenght of fruits (comprimento médio dos frutos); DAF= average diameter of fruits (diâmetro médio dos frutos); PTA= average pulp thickness (espessura média da polpa); L/D= lenght/diameter ratio (razão comprimento/diâmetro); $\mathrm{NAS}=$ average number of seeds (número médio de sementes); WAS = average weight of seeds (massa média de sementes); WAP $=$ average weight of placenta (massa média da placenta); WAP $+\mathrm{S}=$ average weight of placenta + seeds (massa média da placenta + sementes); TPP $=$ total production/plant (produção total por planta); $\mathrm{NFP}=$ number of fruits/plant (número de frutos por planta); WAF= average weight of fruits (massa média dos frutos); ETYH= estimated total yield/ha (produtividade total estimada/ha); ECYH= estimated marketable yield/ha (produtividade comercial estimada por ha).

et al. (2009) obtained results similar to those observed in the present study, with yield of $4.1 \mathrm{~kg} /$ plant and 18.3 fruits/ plant for the hybrid Eppo cultivated in coconut fiber with fertirrigation.

The average mass of the fruits was $200 \mathrm{~g}$, this being less than that observed by Charlo et al. (2009) who found a mean of $224 \mathrm{~g}$ /fruit. These differences in average fruit weight are probably due to different climatic conditions of different experiments.

The estimated total yield per hectare was $98.0 \mathrm{t} \mathrm{ha}^{-1}$ and the estimated commercial yield per hectare $97.3 \mathrm{t}$ ha $^{-1}$ in 84 days of harvest (105 to 189 DAT) (Table 3). Queiroga et al. (2002), evaluating the utilization of different materials as mulch, in the cultivation of the sweet pepper cv. Yolo Wonder, obtained a minimum yield of $4.1 \mathrm{tha}^{-1}$ and maximum of $10.3 \mathrm{t} \mathrm{ha}^{-1}$. Furlan et al. (2002), studying irrigation water depths and application of $\mathrm{CO}_{2}$ in the production of sweet pepper cv. Mayata in a greenhouse, observed a maximum yield of $14.3 \mathrm{tha}^{-1}$. These differences in yield are due mainly to the cultivars and production techniques employed and also because of the production cycle. The productivity in this experiment is within the range of 80 to $110 \mathrm{t} / \mathrm{ha}$ expected in the pepper cultivation in greenhouse. However the yields from Queiroga et al. (2002) and Furlan et al. (2002) are lower than expected.

Rosa (1995) used a non-climatized protected environment to study a population of 20,000 plants/ha of the hybrid Zarco and obtained a total yield of $56.4 \mathrm{t} \mathrm{ha}^{-1}$, but did not define the cultivation cycle. Pereira (1995), studying the sweet pepper hybrid Amarelo Marengo Hy in a greenhouse, obtained a yield of $13.1 \mathrm{t} \mathrm{ha}^{-1}$ with 20,000 plants/ha.

Charlo et al. (2009) observed for the hybrid Eppo cultivated in coconut fiber with fertirrigation an estimated total yield of $102.9 \mathrm{tha}^{-1}$ and marketable yield of $102.6 \mathrm{tha}^{-1}$ over two months of harvest. In general, the yield obtained was superior to means found in other growing systems, which shows that cultivation in coconut fiber with fertirrigation is very promising.

For the classification of the fruits based on the São Paulo (1998) standards, the cultivar was classified as belonging to the square group (shape). The subgroup (coloration) was the subgroup yellow. With respect to the class (length), the fruits were placed in the class 12 (12 to $15 \mathrm{~cm}$ in length). The subclass of the fruits was subclass 8 ( 8 to $10 \mathrm{~cm}$ in diameter). For the category, the produce was classified as Extra.

It is concluded that, for this cultivation system, the growth of the plants was continuous throughout the cycle, where the fruits accumulated the greatest quantity of dry matter. The marketable production of mature fruits was $97.3 \mathrm{t}$ per hectare, where the produce was classified as Extra.

\section{ACKNOWLEDGEMENTS}

We thank Fundação de Apoio a Pesquisa do Estado de São Paulo (FAPESP) for awarding a master's studentship to the first author of the work (Process n $n^{\circ} .05 / 58235-7$ ), research startup grant to the second author (Process $n^{\circ}$. 05/54004-0) and research assistance grant (Process n $n^{\circ}$. 05/587136). Dr. A. Leyva provided help with translation and editing of the manuscript.

\section{REFERENCES}

BAKKER JC; VAN UFFELEN JAM. 1988. The effects of diurnal temperature regimes on growth and yield of sweet pepper. Netherlands Journal of Agricultural Science 36: 201-208.

BEESE F; HORTON R; WIERENGA PJ. 1982. Growth and yield response of chile pepper to trickle irrigation. Agronomy Journal 74: 556-561.

BENINCASA MMP. 1988. Análise de crescimento de plantas. Jaboticabal: Funep. 42p.

BHATT RM; SRINIVASA RAO NK. 1997. Growth and photosynthesis in bell-pepper as affected by sink manipulation. Biologia Plantarum 39: 437-439.

CHARLO HCO; CASTOLDI R; FERNANDES C; VARGAS PF; BRAZ LT. 2009. Cultivo de híbridos de pimentão amarelo em fibra da casca de coco. Horticultura Brasileira 27: 155-159.

CLAPHAM WM; MARSH HV. 1987. Relationship of vegetative growth and pepper yield. Canadian Journal of Plant Science 67: 521-530. 
EVANS GC. 1972. The quantitative analysis of plant growth. Oxford: Blackwell Scientific Publications. 734 p.

FACTOR TL. 2003. Utilização do efluente de biodigestor no cultivo de pimentão em substratos, sob ambiente protegido. Jaboticabal: UNESP-FCAV. 88p (Tese mestrado).

FONTES PCR; DIAS EN; SILVA DJH. 2005. Dinâmica do crescimento, distribuição de matéria seca na planta e produção de pimentão em ambiente protegido. Horticultura Brasileira 23: 94-99.

FRIZZONE JA; GONÇALVES ACA; REZENDE R. 2001. Produtividade do pimentão amarelo, Capsicum annum L., cultivado em ambiente protegido em função do potencial mátrico de água no solo. Acta Scientiarum 23: 1111-1116.

FURLAN RA; REZENDE FC; ALVES DRB; FOLEGATTI MV. 2002. Lâmina de irrigação e aplicação de $\mathrm{CO}_{2}$ na produção de pimentão cv. Mayata, em ambiente protegido. Horticultura Brasileira 20: 547-550.

HALL AJ. 1977. Assimilate source-sink relationship in Capsicum annum. L. The dynamics of growth in fruiting and deflorated plants. Australian Journal of Plant Physiology 4: 623-636.

HOFFMANN R; VIEIRA S. 1977. Análise de regressão-uma introdução à econometria. São Paulo: HUCITEC-EDUSP. 399 p.

HUNT R. 1990. Basic growth analysis. London: Unwin Hyman. 112 p.
MILLER CH; McCOLLUM RE; CLAIMON S. 1979. Relationships between growth of bell peppers (Capsicum anunum L.) and nutrient accumulation during ontogeny in field environments. Journal of American Society for Horticultural Science 104: 852-857.

NEGREIROS MZ. 1995. Crescimento, partição de matéria seca, produção e acúmulo de macronutrientes de plantas de pimentão (Capsicum annum L.) em cultivo podado e com cobertura morta. Viçosa: UFV. $187 \mathrm{p}$ (Tese doutorado).

NILWIK HJM. 1981. Growth analysis of sweet pepper (Capsicum annum L.) 2. Interacting effects of irradiance, temperature and plant age in controlled conditions. Annals of Botany 48: 137-146.

PEREIRA EC. 1995. Avaliação do crescimento $e$ da produtividade de pimentão amarelo (Capsicum annum L.) sob diferentes potenciais matriciais de água no solo, em condições de casa de vegetação. Botucatu: UNESP-FCA. $61 \mathrm{p}$ (Tese mestrado).

QUEIROGA RCF; NOGUEIRA ICC; BOTELHO NETO F; MOURA ARB; PEDROSA JF. 2002. Utilização de diferentes materiais como cobertura morta do solo no cultivo de pimentão. Horticultura Brasileira 20: 416-418.

ROCHA MC; CARMO MGF; FERNANDES MCA; COSTA ESP; MANERA TC; GEDDA AEC; COELHO AA. 2004. Características químicas de frutos de pimentão de três cultivares pulverizadas com biofertilizante Agrobio e Oxicloreto de cobre. In: CONGRESSO BRASILEIRO DE OLERICULTURA, 44. Resumos... Campo Grande: SOB (CD-ROM).

ROSA JA. 1995. Efeito da lâmina de água sobre a produção de pimentão amarelo em estufa plástica. Horticultura Brasileira 13: 110.

SÃO PAULO (Estado). 1998. Secretaria de Agricultura e Abastecimento. Programa paulista para a melhoria dos padrões comerciais e embalagens de hortifrutigranjeiros. Classificação de pimentão. São Paulo. não paginado.

SCOTT HD; BATCHELOR JT. 1979. Dry weight and leaf area production rates of irrigated determinate soybeans. Agronomy Journal 71: 776-782.

SILVA EC; RABELLO TM; MACIEL GM. 2005, 15 de novembro. Avaliação de cultivares de pimentão em cultivo protegido no sistema hidropônico (NFT). Disponível em http:// www.unifenas.br/neol/pdfs/pimentãohidr.pdf. SOUZAPVD. 1995. Optimización dele produccion de plantones de citricos en vivero: inoculación con micorrizas vesiculares arbusculares. Valencia: Universidad Politécnica de Valencia. 201 p. (Tesis doctoral).

SYNGENTA. 2009, 12 de dezembro. Pimentão. Disponível em http://www.syngenta.com.br/ pt/produtosemarcas/sementes/vegetais/Pages/ pimentao-hibrido-eppo.aspx.

TRANI PE; CARRIJO OA. 2004. Fertirrigação em hortaliças. Campinas: Instituto Agronômico. 53 p. 